|| Print ISSN: 2589-7837 || Online ISSN: 2581-3935 ||

International Journal of Medical Science and Diagnosis Research (IJMSDR)

Available Online at www.ijmsdr.com

NLM (National Library of Medicine ID: 101738824)

\title{
MICRO BIOLOGY OF PERIODONTAL DISEASE- A REVIEW
}

\author{
Dr. Shilpa Jaryal ${ }^{1}$, Dr. Gurpreet Kaur ${ }^{2}$, Dr Jageer Chinna ${ }^{3}$, Dr Jannat Sharma ${ }^{4}$ \\ ${ }^{1}$ MDS Post Graduate Student, Department of Periodontology and Oral Implantology, National Dental \\ College and Hospital, Derabassi, Mohali, Punjab. \\ ${ }^{2}$ HOD, Department of Periodontology and Oral Implantology, National Dental College and Hospital, \\ Derabassi, Mohali, Punjab \\ ${ }^{3}$ (BDS) Office Administrator, Aviation Dental Calgary, Alberta, Canada \\ ${ }^{4}$ (BDS) Dental Administrator, Canadian Academy of Dental Hygiene, Mississauga, ONTARIO, Canada
}

\section{Conflicts of Interest: Nil}

Corresponding author: Dr Jageer Chinna

DOI: https://doi.org/10.32553/ijmsdr.v5i6.808

\begin{abstract}
:
Periodontal diseases are inflammatory and destructive diseases of the dentogingival complex associated with specific periodontal pathogens inhabiting periodontal pockets. Periodontal diseases lead to damage of the periodontal tissues supporting the teeth (bone and connective tissue) and affect the quality of life of the affected individuals: poor alimentation, tooth loss, social and financial problems. Although it is generally considered that the disease has multifactorial etiology, data show that some specific Gramnegative microorganisms in the subgingival plaque biofilm play a major role in the initiation and progression of periodontitis. Porphyromonas gingivalis, Treponema denticola and Tannerella forsythia form a consortium in the subgingival biofilm and are regarded as the principal periodontopathogenic bacteria. Other microorganisms that have been implicated as predominant species in the disease process are: Aggregatibacter actinomycetemcomitans, Fusobacterium nucleatum, Prevotella intermedia, Campylobacter rectus, Peptostreptococcus migros, Eikenella corrodens. In periodontitis, the initiation of the disease is the colonization of the tissues by these pathogenic species. The next step is bacterial invasion or invasion by pathogenic products into the periodontal tissues, interactions of bacteria or their substances with host cells, and this directly/indirectly causes degradation of the periodontium, resulting in tissue destruction.
\end{abstract}

Keywords: periodontal disease, periodontal pathogens, microbiology.

\section{Introduction:}

The reserch on the microbiology of periodontal health and diseases has been the focus of intense investigation for several decades. Microbial biofilm in the gingival sulcus around teeth is the most important cause of the periodontal diseases. It is a structured community of bacterial cells enclosed in a self produced polyemeric matrix.[1] Although more than 700 different species are present in subgingival microbiota [2-4] only a few of these species are actually involved in the initiation and progression of the periodontal disease process. Moreover, research on the etiopathogenesis of periodontal diseases has suggested the role of environmental behavioral[6-
7], and [8] risk factors in periodontal disease progression but most, if not all forms of periodontitis, should be viewed primarily as infectious diseases. Many technological advances have occurred in molecular techniques in the last few decades which have provided us the capability of performing high- throughput analysis of a large number of samples, circumventing some of the limitation of culturing techniques.

\section{Historical Aspect}

Dental plaque the period from 1880 to 1930 is known as 'Golden age of microbiology'[9]. Wet mounts or stained smear. Scientists identified four different groups of potential etiologic agents 
(amoebae,siprochetes,fusiforms and streptococci) for various periodontal diseses using the techniques available at that time (wet mounts or stained smear microscopy). Researchers suggested the specific plaque hypothesis based on these findings. However with the advancements in bacterial identification techniques, many other bacterial species were identified in dental plaque derived from periodontitis patients. Studies conducted between 1930 and 1970 failed to identified any specific microorganism as the etiologic agent of periodontal diseases which leads to the proposal of non- specific plaque hypothesis, according to which gross accumulation of dental plaque would be necessary and sufficient to cause periodontitis.

Later on, with the advancement in the field of microbiology, immunology and molecular biology, numerous studies concluded a pututative pathogenic role of many bacteria, mainly gram negative species in the etiopathogenesis of the diseases. These species include A.actinomycetemcomitans, Tannerella forsythia, Porphyromonas gingivalis, Prevotella intermedia, Campylobacter Rectus, Fusobacterium nucleatum, and Treponema denticola.

Virulence Factors produced by these micro organisms have been identified and their role in the periodontal destruction is well established.

\section{BACTERIAL TAXONOMY}

Systemic classification and categorization of organisms into ordered groups is called taxonomy. A working knowledge of bacterial taxonomy is essential for understanding various bacterial species involved in the periodontal disease progression. Although higher organisms are classified according in their evolutionary pathways (i.e. phylogenetically), bacteria cannot be similarly categorized because of insufficiency in their morphological features.

Bacterial classification according to phenotypic features-

Morphology - ( Cocci, bacilli, Siprochetes)

Staining properties - (Gram- positive, Gram- negative etc.)

Spore formers or non -spore formers.

Cultural requirements- (Aerobic, Facultative, Anaerobic, Anaerobic etc.

Biochemical reactions (saccharolytic and asaccharolytic according to sugar fermentation reaction)

Antigenic structure (serotypes)

\section{Establishing an organism as periodontal pathogen.}

- Periodontal diseases are caused by a variety of micro- organisms that reside at or below the gingival margin in the form of plaque biofilm. Because there is a complex microbiota involved in the formation of plaque biofilm, first we need to distinguish the pathogenic bacterial species from the host compatible species.
- Secondly, we need to devise treatment methods that can decrease the pathogens while maintaining host - compatible species.

- To establish an association of an organism with disease pathogenesis, three rules for experimental proof for the pathogenicity of an organism were presented in 1883 by the German bacteriologist, Robert Koch, and a fourth rule was appended by smith (1905)[10]. These rules of proof are often referred to as Koch's Postulates.

These are,

The suspected casual organism must be constantly associated with the disease.

The suspected casual organism must be isolated from an infected host and grown in pure culture.

When a healthy susceptible host is included with the pathogen from pure culture, symptoms of the original disease must develop.

The same pathogen must be re- isolated from host infected under experimental conditions. 
However, periodontal diseases are not caused by a single organism which is the cornerstone of Koch's postulates. To better identify periodontopathogenic bacterial candidates Koch's postulates were replaced with Socransky's postulates[11].

These include the following:

The organism must be found in relatively high numbers in proximity to the periodontal lesion.

The organism must be absent, or present in much smaller numbers in periodontally healthy subjects or in subjects with other froms of periodontal disease.

The organism must have high level of serum, salivary and gingival crevicular fluid antibody developed against it is periodontally diseased subjects.

The organism must be found to produce virulence factors in vitro, which can be correlated with clinical histopathology.

The organism must mimic similar pathogenic properties in an appropriate animal model.

Clinical improvement following treatment must eliminate the putative pathogen from the periodontal lesion.

\section{SUBGINGIVAL MICROBIAL COMPLEXES}

In a landmark study, Socransky et al. (1998) examined over 13000 subgingival plaque samples from 185 adult subjects and used DNA hybridization methodology and community coordination techniques to demonstrate the presence of specific microbial groups within the dental plaque.

$1^{\text {st }}$ complex (Red complex): Tamerellaforsythia, Polphyromonas gingivalis, and Treponema denticola. $2^{\text {nd }}$ complex (Orange complex): Eubactenium nodatum, Campylobacter rectus, Campylobacter showae, Streptococcus constellatus, and Campylobacter gracilis.

$3^{\text {rd }}$ complex (Yellow complex): Streptococcussanguis, S. oralis, S. mitis S. gordonï and S. intermedia. $4^{\text {th }}$ complex (Green complex): Campylobacter concisus Eikenella corrodens, and Actinobacillus actinomycetemcomitans serotype a.

$5^{\text {th }}$ complex (purple complex): Veillonella parvula and Actinomyces odontolyticus.

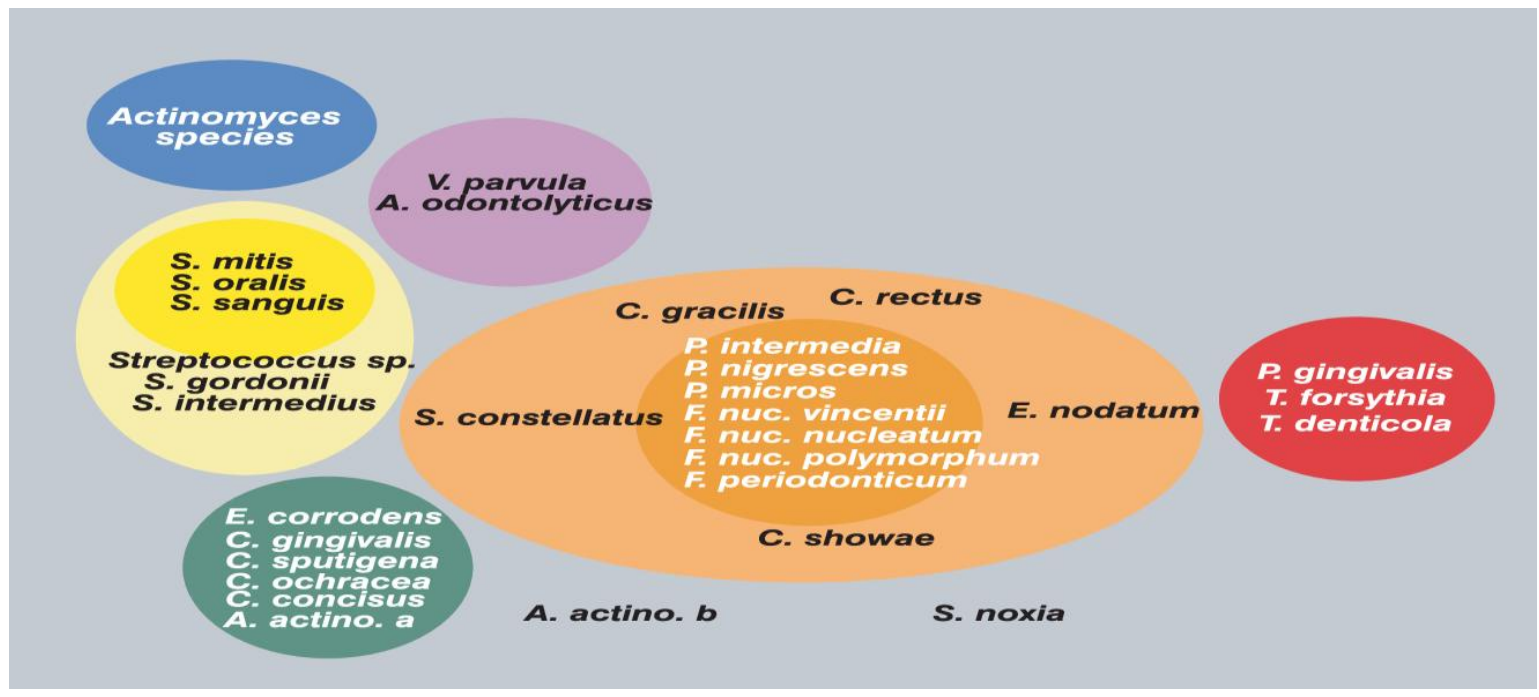

Figure 1: The subgingival microbial complexes as proposed by Socransky et al (1998) 


\title{
PERIODONTAL CONDITION AND ASSOCIATED MICRO-ORGANISMS
}

\author{
Periodontal Health Streptococcus oralis, Streptococcus sanguis, Streptococcus mitis, Actinomyces \\ gerencseriae, Actinomyces naeslundii, Fusobacterium species, Prevotella nigrescens, \\ Veillonella species.
}

Gingivitis

Lactobacillus species, Actinomyces naeslundii, Peprostreptococcus micros, Streptococcus anginosus, Fusobacterium nucleatum, P. intermedia, Winonalla parvula, Campylobacter species, Haemophilus species, Selenomonas Species, Treponema species.

Periodontitis with Eubacterium brachy, Eubacterium nodatum, Mogibacterium timidium, Parvimonas slow/moderate rate of micra, Peptostreptococcus stomatis, Parvimonas micra, Tannerella forsythia, progression (Grade Fusobacterium nucleatum, Porphyromonas gingivalis, Prevotella intermedia, $\mathrm{A} / \mathrm{B})$ Prevotella loescheii, Dialister pneumosintes, Campylobacter rectus, Treponema species.

Periodontitis with Aggregatibacter actinomycetemcomitans, Porphyromonas gingivalis, Tannerella rapid rate of forsythia, Prevotella intermedia, Prevotella nigrescens, Eikenella corrodens, progression (Grade C) Selenomonas sputigena, F. nucleatum, Campylobacter rectus, Peptostreptococcus micros, Campylobacter concisus.

Refractory Aggregatibacter actinomycetemcomitans, Streptococcus constellatus/intermedius, periodontitis Tannerella forsythia, P. gingivalis, T. denticola, Campylobacter rectus, Eikenella corrodens.

Necrotizing ulcerative Prevotella intermedius, Treponema species, Selenomona species, Fusobacterium gingivitis/periodontitis species, Candida species.

Periodontal pathogen, and their virulence factors, their actions:

\begin{tabular}{|c|c|c|c|}
\hline Mifcroorganism & $\begin{array}{l}\text { Adhesion/ } \\
\text { Colonization }\end{array}$ & Virulence factors & Actions \\
\hline $\begin{array}{l}\text { Aggregatibactor } \\
\text { actimomycetemco } \\
\text { mitans }\end{array}$ & $\begin{array}{l}\text { Pilli } \\
\text { Vesicle } \\
\text { Capsular } \\
\text { antigen }\end{array}$ & $\begin{array}{l}\text { - Leukotoxin } \\
\text { - Cytolethal } \\
\text { distending } \\
\text { toxin (CDT) } \\
\text { - Fc binding } \\
\text { - Collagenases } \\
\text { - LPS } \\
\text { - Proteases } \\
\text { - CagE- } \\
\text { homologue } \\
\text { OMP-1 }\end{array}$ & $\begin{array}{l}\text { - Kills neutrophils, lymphocytes and } \\
\text { - Aponocytes } \\
\text { - Deactivation of Ig's } \\
\text { - Disintegration of collegen } \\
\text { - Potent stimulator of II } 1 \text {, PGE } 2 \text { and } \\
\text { - Cleavage of } 1 \text { g's. } \\
\text { - Host cell cytotoxicity } \\
\text { - Induce apoptosis of epithelia, } \\
\text { endothelia, osteoblasts, and } \\
\text { Iymphocytes ; activate; CD4+ T-cell- } \\
\text { mediated immume response as sociated } \\
\text { with osteoclastogenic activity } \\
\text { Induce IgG and CD4 + T-cell-mediated } \\
\text { immunity }\end{array}$ \\
\hline
\end{tabular}




\begin{tabular}{|c|c|c|c|}
\hline Microorganism & $\begin{array}{l}\text { Adhesion } \\
\text { Colonization }\end{array}$ & $\begin{array}{l}\text { Virulence } \\
\text { factors }\end{array}$ & Actions \\
\hline $\begin{array}{l}\text { Aggregatibactor } \\
\text {.actinomycetemc } \\
\text { omitans }\end{array}$ & $\begin{array}{l}\text { Pilli } \\
\text { Vesicle } \\
\text { Capsular } \\
\text { antigen }\end{array}$ & $\begin{array}{l}\text { - OMP-100 } \\
\text { GroEL } \\
\text { (Hsp60) } \\
\text { 65-kDa } \\
\text { protein } \\
\text { Surface } \\
\text { proteins } \\
\text { (SAM: } \\
14-79 \\
\text { kDa) }\end{array}$ & $\begin{array}{l}\text { - Bacterial adhesin, invasin, and serum } \\
\text { resistance factor; induce host } \\
\text { cytokine production. } \\
\text { - Stimulate pro-inflammatory cy tokine } \\
\text { release; modulate antibacterial } \\
\text { immunity; stimulate bone resorption } \\
\text { in vitro (via osteoclast activity) } \\
\text { - Modulate immune response by binding } \\
\text { to IL-1OR (CSIF) } \\
\text { Stimulate protective immunity (via IgG } \\
\text { activity) }\end{array}$ \\
\hline
\end{tabular}

\begin{tabular}{|c|c|c|c|}
\hline $\begin{array}{l}\text { Micro- } \\
\text { organism }\end{array}$ & $\begin{array}{l}\text { Adhesion/ } \\
\text { Colonization }\end{array}$ & $\begin{array}{l}\text { Virulence } \\
\text { factors }\end{array}$ & Actions \\
\hline P.gingivalis & $\begin{array}{l}\text { Pilli } \\
\text { Vesicle } \\
\text { Capsular } \\
\text { antigen }\end{array}$ & $\begin{array}{l}\text { Proteases } \\
\text { (gingipains) } \\
\text { - LPS } \\
\text { - Hemolysins } \\
\text { Volatile } \\
\text { sulfur } \\
\text { compounds } \\
\text { Ammonia } \\
\text { - Indole }\end{array}$ & $\begin{array}{l}\text { - Degradation of Ig, complement factors. } \\
\text { - Potent stimulator of IL 1, PGE2 and } \\
\text { - Causes agglutination and lysis of } \\
\text { erythrocytes. } \\
\text { - Host cell cytotoxicity } \\
\text { - Host cell cytotoxicity } \\
\text { - Host cell cytotoxicity }\end{array}$ \\
\hline
\end{tabular}

\begin{tabular}{|c|c|c|c|}
\hline $\begin{array}{l}\text { Micro- } \\
\text { organism }\end{array}$ & $\begin{array}{l}\text { Adhesion/ } \\
\text { Colonization }\end{array}$ & Virulent factors & Actions \\
\hline T. denticola & $\begin{array}{l}\text { Major surface } \\
\text { protein (MSP) } \\
\text { Fibronectin } \\
\text { binding } \\
\text { adhesins }\end{array}$ & $\begin{array}{l}\text { - } \\
\text { - Proteases } \\
\text { - Dentilisin } \\
\text { - Major surface } \\
\text { protein (MSP) } \\
\text { Phospholipase C } \\
\text { (PLC) } \\
\text { - H2S and methyl } \\
\text { mercaptan }\end{array}$ & $\begin{array}{l}\text { - Potent stimulator of IL 1, PGE2 and } \\
\text { TNF } \\
\text { Degradation of extracellular matrix } \\
\text { - Pleiotropic effects. Crucial for the } \\
\text { virulence of T.denticola } \\
\text { - Cytotoxic for a wide variety of cells } \\
\text { - Directly or indirectly damages } \\
\text { tissue by hydrolys is of membrane } \\
\text { phospholipids } \\
\text { - Cytotoxic effects that is primarily } \\
\text { due to inhibition of cytochrome } \\
\text { oxidases. }\end{array}$ \\
\hline
\end{tabular}




\begin{tabular}{|c|c|c|c|}
\hline $\begin{array}{c}\text { Micro- } \\
\text { organism }\end{array}$ & $\begin{array}{l}\text { Adhesion/ } \\
\text { Colonization }\end{array}$ & Virulent factors & Actions \\
\hline T: denticola & $\begin{array}{l}\text { Major surface } \\
\text { protein (MSP) } \\
\text { Fibronectin } \\
\text { binding } \\
\text { adhesins }\end{array}$ & $\begin{array}{l}\text { - Proteases } \\
\text { - Dentilisin } \\
\text { - Major surface } \\
\text { - Protein (MSP) } \\
\text { - Phospholipase C } \\
\text { (PLC) } \\
\text { HzS and methyl } \\
\text { mercaptan }\end{array}$ & $\begin{array}{l}\text { - Potent stimulator of II } 1 \text {. PGE2 and } \\
\text { - Degradation of extracellular matrix } \\
\text { - Pleiotropic effects. Crucial for the } \\
\text { virulence of T.denticola } \\
\text { - Cytotoxic for a wide variety of cells } \\
\text { - Directly or indirectly damages } \\
\text { tissue by hydrolysis of membrane } \\
\text { phospholipids } \\
\text { - Cytotoxic effects that is primarily } \\
\text { due to inhibition of cytochrome } \\
\text { oxidases. }\end{array}$ \\
\hline
\end{tabular}

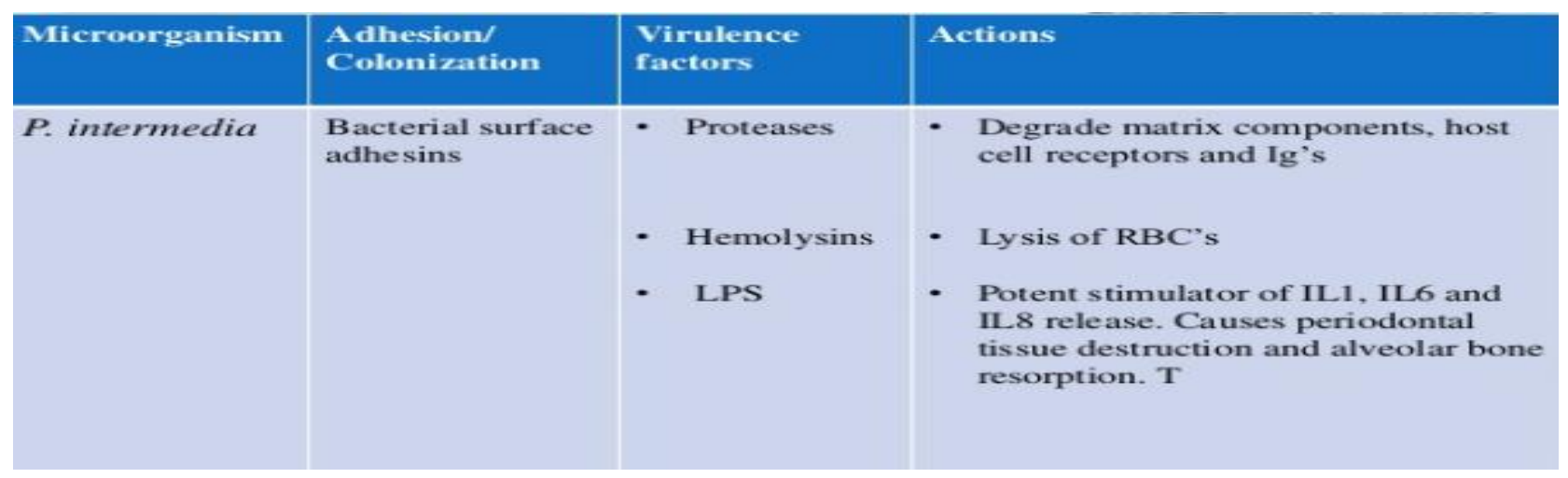

VIRUSES

More recently, viruses including Cytomegalo, Epstein Barr, Papilloma and Herpes simplex have been proposed to play a role in the etiology of periodontal diseases, possibly by changing the host response to the local subgingival microbiota (Contreras \& Slots 2000)[11].

Human Cytomegalo, Epstein Barr and Herpes simplex viruses were found more frequently in deteriorating periodontal sites than in control, stable periodontitis sites in the same subject (Kamma et al 2001)[12].

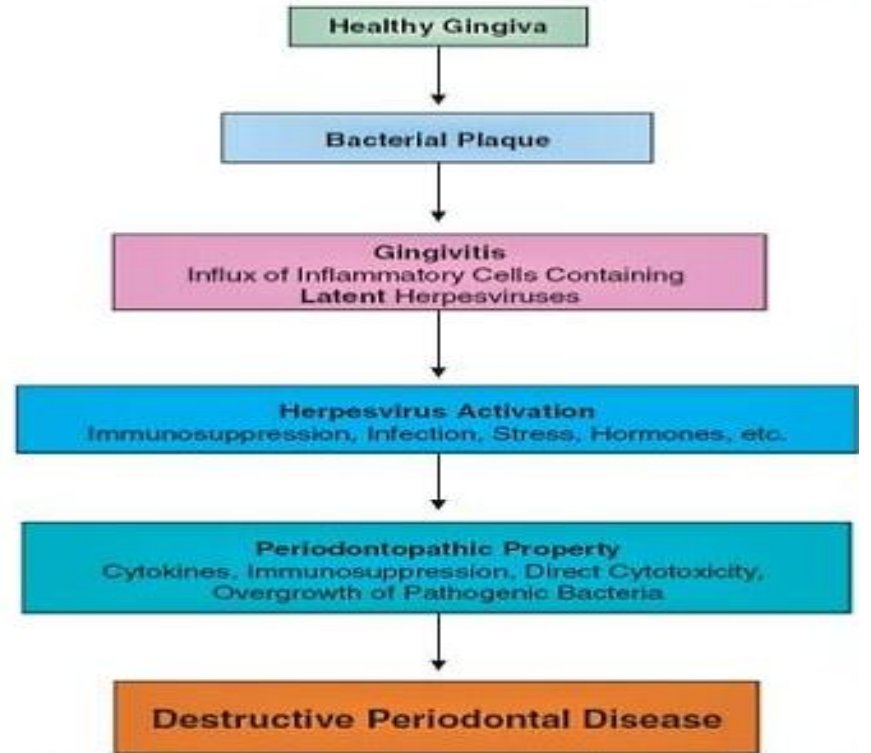

Figure 2: Herpesviruses in destructive periodontal disease. 


\section{FUNGI}

Hannula J, Dogan B, Slots (2001) showed geographical differences in the subgingival distribution of C. albicans serotypes and genotypes and suggested geographic clustering of $\mathrm{C}$. albicans clones in Subgingival samples of Chronic Periodontitis patients[12].

Reynaud AH (2001) found a weak correlation between yeasts in periodontal pockets[13].

Rubio NA eta al (2015) also showed fungal invasion of connective tissue in patients with gingivalperiodontal disease[14].

\section{NEWER PERIODONTAL PATHOGENS:}

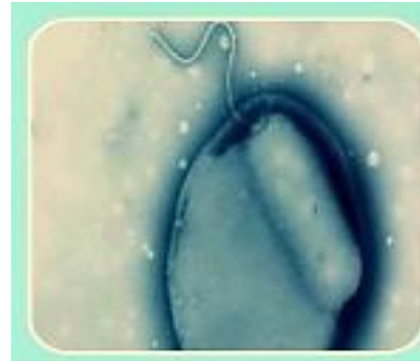

Bdelloyibrio

bacteriovoris

are small flagellate, motile, G-ve obligatory predators which invade and kill other Gramnegative bacteria.

It attacks Aa.comitans.

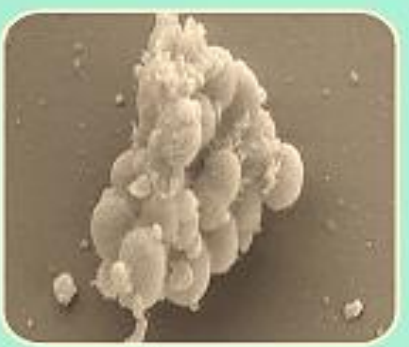

Dialister pneumosintes

G-ve, Obligately anaerobic, rodshaped.

Implicated in periodontitis (Ghayoumi et al, 2002).

Detected in $83 \%$ of patients having severe periodontitis (Contreras A, et al. 2000 , Slots 2002)

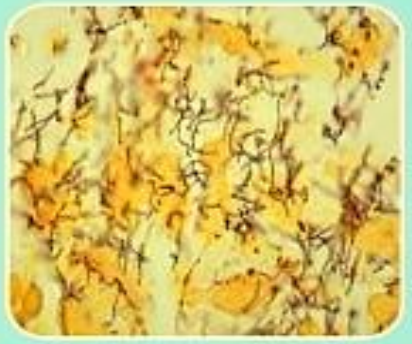

Treponema lecithinolyticum

Saccharolytic spirochaete.

More pronounced in aggressive periodontitis.( Park et al 2002)

T. socranskii, $T$. lecithinolyticum good indicators for periodontitis.

(Annette Moter et al 2006)

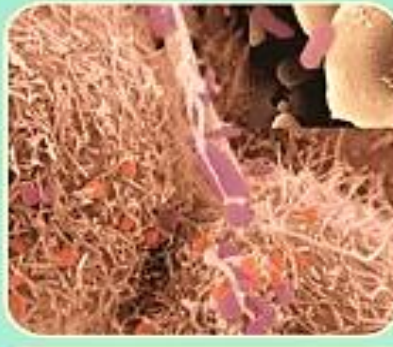

Filifactor alocis

G+ve, obligately anaerobic rod.

GAP/CP harboured F. alocis, it was rarely detected in the control group. (Schlafer et al 2010).

Virulence properties that may enhance its ability to persist in periodontal pocket. (Wilson Aruni et al. 2011)

$38 / 42$

MICROBIAL DIAGNOSTIC TESTINGMETHOD DESCRIPTION PROS CONS:

\begin{tabular}{|l|l|l|l|}
\hline METHOD & DESCRIPTION & PROS & CONS \\
\hline Bacterial Culture & $\begin{array}{l}\text { - Currently the gold } \\
\text { standard. } \\
\text { - Determines the } \\
\text { presence of the } \\
\text { different species }\end{array}$ & $\begin{array}{l}\text { - Evaluates the } \\
\text { antibiotic } \\
\text { susceptibility } \\
\text { - Estimates the } \\
\text { number of isolated } \\
\text { bacteria }\end{array}$ & $\begin{array}{l}\text {-No culturable } \\
\text { bacteria (T. denticola } \\
\text { and T. Forsy thensis) }\end{array}$ \\
\hline $\begin{array}{l}\text { Immunological } \\
\text { diagnostic methods }\end{array}$ & $\begin{array}{l}\text { - Direct } \\
\text { immunofluorescence } \\
\text { - Indirect } \\
\text { immunofluorescence } \\
\text { - Flow cytometry } \\
\text { - Latex agglutination } \\
\text { - Enzyme-linked } \\
\text { immune absorbent } \\
\text { assay (ELISA) }\end{array}$ & $\begin{array}{l}\text { - Used to establish the } \\
\text { nature of the bacterias } \\
\text { in the biofilm } \\
\text { - Calculates the } \\
\text { percentage of bacteria } \\
\text { - Greater sensitivity } \\
\text { and specificity }\end{array}$ & $\begin{array}{l}\text { Cannot be used to } \\
\text { assess bacterial } \\
\text { susceptibilities }\end{array}$ \\
\hline
\end{tabular}




\begin{tabular}{|l|l|l|l|}
\hline METHOD & DESCRIPTION & PROS & CNS \\
\hline $\begin{array}{l}\text { Enzymatic detection } \\
\text { methods }\end{array}$ & $\begin{array}{l}\text { - Doesn't detect } \\
\text { bacterias directly, } \\
\text { determines the } \\
\text { presence of enzymes } \\
\text { that bacterias produce } \\
\text { - BANA (benzoil } \\
\text { arginine naftil amida) }\end{array}$ & $\begin{array}{l}\text { - Enables detection of } \\
\text { certain bacterial } \\
\text { species capable of } \\
\text { producing tripsin } \\
\text { enzymes as a } \\
\text { virulence factor }\end{array}$ & $\begin{array}{l}\text { - Low specificity and } \\
\text { sensitivity } \\
\text { - High } \\
\text { concentrations of } \\
\text { microorganisms }\end{array}$ \\
$\begin{array}{l}\text { Molecular biology } \\
\text { techniques of DNA }\end{array}$ & $\begin{array}{l}\text { - Polymerase chain } \\
\text { reaction (PCR): } \\
\text { amplifies DNA } \\
\text { strands }\end{array}$ & $\begin{array}{l}\text { - High specificity } \\
\text { - Diagnosis of major } \\
\text { periodontal pathogenic } \\
\text { bacteria } \\
\text { - Does not need living } \\
\text { microorganisms }\end{array}$ & $\begin{array}{l}\text { quantification } \\
\text { - Ease of } \\
\text { contamination in the } \\
\text { process. } \\
\text { - Inability to provide } \\
\text { information on the } \\
\text { sensitivity to } \\
\text { antibiotics }\end{array}$ \\
\hline
\end{tabular}

\section{Conclusion}

The results of current genome study projects of several periodontopathogens will provide detailed information about the etiology of periodontal diseases, and will likely show new possibilities for the treatment and prevention of periodontal diseases.In the near future, it is expected that the correlation between biofilm maturation and activation of specific genes of the inner microorganisms will be clarified at the molecular level.

\section{References}

1. Haffajee AD,Socransky SS. Microbiology of periodontal diseases: introduction. Periodontology 2000. 2005 Jun;38(1):9-12.

2. Socransky SS. Microbiology of periodontal disease-present status and future considerations. Journal of

3. periodontology. 1977 Sep;48(9):497504.

4. Moore WE. Microbiology of periodontal disease. Journal of periodontal research. 1987 Sep;22(5):335-4 1.

5. Haffajee AD,Socransky SS. Introduction to microbial aspects of periodontal biofilm communities, development and treatment. Periodontology 2000. 2006 Oct;42(1):7-12.

6. Zambon JJ. Periodontal diseases: microbial factors. Annals of periodontology. 1996 Nov;1(1\}:879-925.

7. Loomer PM. Microbiological diagnostic testing in the treatment of periodontal diseases. Periodontology 2000. 2004 Feb;34(1):49-56.

8. Haffajee AD,Socransky SS,Dzink JL,Taubman MA,Ebersole JL, Smith DJ. Clinical, microbiologicaland immunological features of subjects with destructive periodontal diseases. Journal of clinical periodontology. 1988Apr; 15(4):240-6.

9. Armitage GC. Periodontal diseases: diagnosis. Annals of Periodontology. 1996 Nov; 1(1):37-215.

10. Teles R, Teles F, Frias-Lopez J, Paster B, Haffajee A. Lessons learned and unlearned in periodontal microbiology.Periodontology 2000. 2013Jun;62(1):95-162.

11. Nonnenmacher C, Mutters R, De Jacoby LF. Microbiological characteristics of subgingival microbiota in adult periodontitis,localized juvenile periodontitis and rapidly progressive 
periodontitis subjects. Clinical Microbiology and Infection. 2001Apr $1 ; 7(4): 213-7$.

12. Slots J. Herpesviral-bacterial interactions in periodontal diseases. Periodontol 2000. 2010;52(1):117-140.

13. Rotola A, Cassai E, Farina R, Caselli E, Gentili V, Lazzarotto T, Trombelli L. Human herpesvirus 7, Epstein-Barr virus and human cytomegalovirus in periodontal tissues of periodontally diseased and healthy subjects. J Clin Periodontol. 2008 Oct;35(10):831-7. doi: 10.1111/j.1600-051X.2008.01301.x. Epub 2008 Aug 7. PMID: 18691217.

14. Hannula J, Dogan B, Slots J, Okte E, Asikainen S. Subgingival strains of Candida albicans in relation to geographical origin and occurrence of periodontal pathogenic bacteria. Oral Microbiol Immunol. 2001 Apr; 16(2):113-8.

15. Reynaud AH, Nygaard-Østby B, Bøygard GK, Eribe ER, Olsen I, Gjermo P. Yeasts in periodontal pockets. J Clin Periodontol. 2001 Sep;28(9):860-4. doi: 10.1034/j.1600-051x.2001.028009860.x. PMID: 11493356.

16. Rubio NA, Puia S, Toranzo S, Brusca MI. Invasión fúngica en tejido conectivo en pacientes con enfermedad gingivoperiodontal [Fungal invasion of connective tissue in patients with gingival-periodontal disease]. Rev Iberoam Micol. 2015 Jan-Mar;32(1) :204.Spanish.doi:10.1016/j.riam.2012.07.00 2. Epub 2012 Jul 21. PMID: 22824245. 